Artikel

\title{
KESANTUNAN BERBAHASA DALAM PEMBELAJARAN \\ BAHASA INDONESIA SISWA KELAS VII \\ SMP NEGERI 1 LABUHAN DELI \\ TAHUN PEMBELAJARAN \\ 2016/2017
}

Oleh

Lidia Marintan Simaremare

NIM 2132111011

Dosen Pembimbing Skripsi

Dr. Abdurahman Adisaputera, M.Hum.

Telah Diverifikasi dan Dinyatakan Memenuhi

Syarat untuk Diunggah pada Jurnal Online

Medan, September 2017

Menyetujui :

Editor,

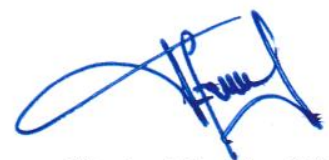

Fitriani Lubis, S.Pd., M.Pd. NIP 197708312008122001
Dosen Pembimbing Skripsi,

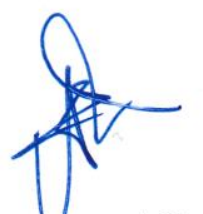

Dr. Abdurabman Adisaputera, M.Hum. NIP 196710011994021001 


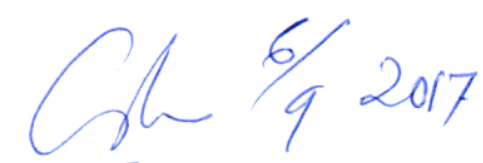

KESANTUNAN BERBAHASA DALAM PEMBELAJARAN

BAHASA INDONESIA SISWA KELAS VII

SMP NEGERI 1 LABUHAN DELI

TAHUN PEMBELAJARAN

2016/2017

\author{
Oleh \\ Lidia Marintan Simaremare (lidiasimaremare14@gmail.com) \\ Dr. Abdurahman Adisaputera, M.Hum.
}

Penelitian ini bertujuan untuk mendeskripsikan bentuk kesalahan sintaksis yang meliputi: (1) realisasi kesantunan berbahasa, (2) penyimpangan prinsip kesantunan berbahasa, dan (3) peringkat penyimpangan prinsip kesantunan berbahasa siswa kelas VII SMP Negeri 1 Labuhan Deli Tahun Pembelajaran 2016/2017. Subjek penelitian ini adalah siswa kelas VII-2 SMP Negeri 1 Labuhan Deli Tahun Pembelajaran 2016/ 2017. Objek penelitian ini adalah tuturan lisan yang berhubungan dengan prinsip kesantunan berbahasa. Hasil dari penelitian ini menunjukkan bahwa (1) kesantunan berbahasa sangat dipengaruhi oleh peringkat langsung dan tidak langsungnya maksud sebuah tuturan itu. (2) Dalam pembelajaran bahasa Indonesia siswa kelas VII SMP negeri 1 Labuhan Deli ditandai dengan penyimpangan prinsip kesantunan Leech yaitu maksim kebijaksanaan.

(3) Peringkat penyimpangan ditandai dengan maksim kebijaksanaan dengan penanda penutur menggunakan diksi kasar, memerintah dan menegur mitra tutur secara langsung.

Kata Kunci: Prinsip Kesantunan Berbahasa, Pragmatik.

\title{
PENDAHULUAN
}

Bahasa merupakan sebuah sarana yang digunakan manusia untuk berkomunikasi. Chaer (2011: 1) mengemukakan bahwa bahasa adalah sistem lambang berupa bunyi, bersifat arbitrer, yang dipergunakan oleh suatu masyarakat untuk bekerja sama, berkomunikasi, dan mengidentifikasikan diri. Sesuai dengan fungsinya, bahasa memiliki peran sebagai penyampai pesan antara manusia satu 
dengan lainnya. Namun, pada kenyataan di lapangan, etika berbahasa yang dimiliki oleh siswa saat ini terkesan buruk. Hal ini dapat dilihat dari siswa yang cenderung kehilangan etika dan sopan santun, baik terhadap guru maupun siswa yang lainnya.

Pada dasarnya kesantunan berbahasa merupakan aspek yang sangat penting untuk membentuk karakter dan sikap seseorang. Dari bahasa yang digunakan seseorang dalam bertutur kepada orang lain, dapat diketahui karakter dan kepribadian yang dimiliki orang tersebut. Selain itu, dengan adanya muatan pendidikan karakter yang harus diterapkan oleh guru-guru di sekolah pada setiap mata pelajaran, khususnya mata pelajaran bahasa Indonesia, prinsip kesantunan berbahasa ini dapat digunakan sebagai materi pendidikan karakter yang diimplikasikan dalam proses pembelajaran.

Berdasarkan observasi semula, ketika peneliti melakukan Program Pengalaman Terpadu (PPLT) di SMP Negeri 1 Labuhan Deli, peneliti melihat bahwa siswa masih sering menggunakan kata-kata yang kurang santun ketika berkomunikasi. Hal ini terjadi bukan hanya di luar kelas bahkan ketika berada di dalam kelas siswa juga menggunakan kata-kata yang kurang santun. Tentu saja hal ini bukan merupakan contoh yang baik karena ketika berada di lingkungan sekolah baik di dalam kelas maupun di luar kelas seharusnya siswa menggunakan bahasa yang santun dalam percakapannya.

Penelitian tentang kesantunan berbahasa juga sudah pernah dilakukan antara lain: Kesantunan Berbahasa Indonesia Pada Tuturan Lisan Siswa Kelas VII SMP Negeri 3 Air Putih Tahun Pembelajaran 2012/2013 oleh Sirait, Penyimpangan Prinsip Kesantunan Berbahasa dalam Interaksi Belajar Mengajar Bahasa Indonesia Siswa Kelas VIII SMP Negeri 3 Sewon oleh Safitri, Kesantunan Berbahasa dalam Kegiatan Diskusi Siswa Kelas XI SMK Dinamika Lampung Utara oleh Ishariyanti, dkk. 
Fenomena di atas mendorong penulis untuk meneliti lebih jauh tentang kesantunan berbahasa dalam pembelajaran bahasa Indonesia. Adapun judul penelitian ini adalah "Kesantunan Berbahasa dalam Pembelajaran Bahasa Indonesia Siswa Kelas VII SMP Negeri 1 Labuhan Deli Tahun Pembelajaran 2016/2017".

\section{METODE PENELITIAN}

Penelitian adalah suatu proses yaitu rangkaian kegiatan yang dilakukan secara terencana dan sistematis. Dalam suatu penelitian, metode memegang peranan yang sangat penting. Hal ini karena semua kegiatan yang akan dilakukan dalam penelitian sangat bergantung pada metode yang digunakan. Sesuai pendapat Arikunto (2002:22) yang menyatakan "metode penelitian merupakan struktur yang sangat penting, sangat ditentukan oleh ketepatan dalam memilih metode penelitian”.

Adapun metode yang digunakan dalam penelitian ini adalah metode deskriptif kualitatif. Penelitian deskriptif menggambarkan apa saja yang saat ini berlaku, khususnya pada bidang kebahasaan, mendiskripsikan sesuatu yang bersifat fakta berdasarkan pada segala sesuatu yang benar-benar terjadi saat ini.

\section{HASIL PENELITIAN DAN PEMBAHASAN}

\section{Realisasi Kesantunan Berbahasa Siswa}

\section{a. Pemenuhan Maksim Kebijaksanaan}

Dari hasil penelitian ditemukan beberapa tuturan yang memenuhi maksim kebijaksanaan. Salah satu tuturannya, yaitu "Knapa di situ tidak ada membahas surat dinas dan bagian-bagiannya?". Tuturan ini dinilai memenuhi maksim kebijaksanaan karena si penutur bersikap menghindari kata-kata yang kurang menyenangkan mitra tuturnya ketika sedang bertanya dengan menggunakan katakata yang sopan. 


\section{b. Pemenuhan Maksim Kedermawanan}

Dari hasil penelitian ditemukan beberapa tuturan yang memenuhi maksim kedermawanan. Salah satu tuturannya, yaitu "Baru yang mana lagi? Saudara Reihan, kami persilahkan! Saudara Reihan kami Persilahkan!". Tuturan ini dinilai memenuhi maksim kedermawaan karena si penutur memiliki sikap kedermawanan kepada salah satu peserta diskusi dengan memberikan kesempatan kepada mitra tuturnya untuk bertanya.

\section{c. Pemenuhan Maksim Penghargaan}

Dari hasil penelitian ditemukan beberapa tuturan yang memenuhi maksim Penghargaan. Salah satu tuturannya, yaitu "Terimakasih sudah menjawab pertanyaan saya.". Tuturan ini dinilai memenuhi maksim penghargaan karena si penutur (penanya) memiliki sikap menghargai mitra tuturnya (penyaji) yang telah menjawab pertanyaannya dengan tidak lupa mengucapkan terimakasih.

\section{d. Pemenuhan Maksim Kesederhanaan}

Dari hasil penelitian ditemukan beberapa tuturan yang memenuhi maksim Penghargaan. Salah satu tuturannya, yaitu "Iya, iya, iya. Maaf.". Tuturan di atas dinilai memenuhi maksim kesederhanaan karena pihak penutur (penyaji B) menunjukkan sikap yang merendahkan hati kepada mitra tuturnya (peserta diskusi) dengan menuturkan kata maaf setelah membuat kesalahan.

\section{e. Pemenuhan Maksim Permufakatan}

Dari hasil penelitian ditemukan beberapa tuturan yang memenuhi maksim Penghargaan. Salah satu tuturannya, yaitu "Iya. Pasti". Tuturan ini memenuhi maksim permufakatan karena memiliki makna Si penutur (penyaji) berusaha membina kecocokan dengan mitra tuturnya (penanya) pada saat menerima sanggahan dari mitra tuturnya . Dengan demikian tuturan ini dinilai santun. 


\section{f. Pemenuhan Maksim Kesimpatian}

Dari hasil penelitian ditemukan beberapa tuturan yang memenuhi maksim Penghargaan. Salah satu tuturannya, yaitu "Aku. Aku aja. Hafiz Syahril...gurindum adalah puisi lama yang berasal dari India.”. Tuturan tersebut dinilai memenuhi maksim kesimpatian karena si penutur (penyaji A) menunjukkan rasa peduli terhadap mitra tutur (Penyaji B) yang sedang kebingungan ketika menjawab pertanyaan. Sehingga, tuturan tersebut dikatakan memenuhi maksim kesimpatian.

\section{g. Pemenuhan Skala Kerugian dan Keuntungan}

Dari hasil penelitian ditemukan beberapa tuturan yang memenuhi maksim Penghargaan. Salah satu tuturannya, yaitu "Ohh. Aku aja yang jelasin. Membaca efektif adalah...". Tuturan tersebut dinilai memenuhi skala kerugian dan keuntungan. Tuturan ini memberikan keuntungan kepada mitra tuturnya. Tuturan ini terkesan memberikan beban biaya (sosial) yang besar kepada diri si penutur.

\section{h. Pemenuhan Skala Pilihan}

Dari hasil penelitian ditemukan beberapa tuturan yang memenuhi maksim Penghargaan. Salah satu tuturannya, yaitu "Ada yang ingin bertanya? Yang ingin bertanya dan berkomentar kami persilahkan!". Tuturan tersebut dinilai memenuhi skala pilihan. Tuturan ini memberi kesempatan kepada mitra tuturnya untuk menentukan pilihan. Tuturan ini tidak membatasi pilihan si mitra tutur.

\section{i. Pemenuhan Skala Ketidaklangsungan}

Dari hasil penelitian ditemukan beberapa tuturan yang memenuhi maksim Penghargaan. Salah satu tuturannya, yaitu "Saya Iqbal Nasution, saya berasal dari kelompok enam. Saya ingin bertanya, apa itu gurindam?". Tuturan tersebut dinilai memenuhi skala ketidaklangsungan. Makna tuturan ini tidak bersifat langsung. 


\section{j. Pemenuhan Skala Keotoritasan}

Dari hasil penelitian ditemukan beberapa tuturan yang memenuhi maksim Penghargaan. Salah satu tuturannya, yaitu "Belum Bu. Dikit lagi.". Tuturan tersebut dinilai memenuhi skala keotoritasan karena si penutur menggunakan kata "Bu" untuk kata ganti gurunya.

\section{k. Pemenuhan Skala Jarak Sosial}

Dari hasil penelitian ditemukan beberapa tuturan yang memenuhi maksim Penghargaan. Salah satu tuturannya, yaitu "Demikian presen, presentasi dari kami.". Tuturan ini dinilai memenuhi skala jarak sosial. Kata "kami" yang digunakan untuk kata ganti diri si penutur dinilai santun.

\section{Penyimpangan Prinsip Kesantunan Berbahasa Siswa}

\section{a. Penyimpangan Maksim Kebijaksanaan}

Dari hasil penelitian ditemukan beberapa tuturan yang menyimpang dari maksim Penghargaan. Salah satu tuturannya, yaitu "Ke depan semuanya...!". Tuturan data tersebut menyimpang dari maksim kebijaksanaan karena si penutur memerintah secara langsung mitra tuturnya. Memerintah mitra tutur secara langsung (tidak menggunakan tolong, dimohon, silahkan) merupakan salah satu indikator yang menyimpang dari maksim kebijaksanaan.

\section{b. Penyimpangan Maksim Kedermawanan}

Dari hasil penelitian ditemukan beberapa tuturan yang menyimpang dari maksim Penghargaan. Salah satu tuturannya, yaitu "Orang ini nggak mau baca $B u \ldots$. .. Tuturan penyaji tersebut termasuk menyimpang dari maksim kedermawanan karena si penutur terlihat dengan jelas telah mempermalukan mitra tuturnya yang tidak berpartisipasi pada saat presentasi, sehingga mengurangi keuntungan bagi pihak lain. 


\section{c. Penyimpangan Maksim Penghargaan}

Dari hasil penelitian ditemukan beberapa tuturan yang menyimpang dari maksim Penghargaan. Salah satu tuturannya, yaitu "Ihhh...Kau nanya fabel aja pun.”. Tuturan tersebut termasuk menyimpang dari maksim penghargaan. Tuturan yang disampaikan oleh salah satu peserta diskusi tersebut terkesan tidak sopan karena peserta diskusi tersebut mengejek sehingga dapat menyakiti hati pihak penanya. Tuturan tersebut akan menjadi santun apabila si penutur (peserta tidak mengejek ataupun merendahkan pertanyaan mitra tuturnya.

\section{d. Penyimpangan Maksim Kesederhanaan}

Dari hasil penelitian ditemukan sebuah tuturan yang menyimpang dari maksim Penghargaan. Adapun tuturannya, yaitu "Nggak Tahu". Tuturan tersebut menyimpang dari prinsip kesantunan berbahasa dengan maksim kesederhanaan. Tuturan tersebut terlihat meminimalkan kehormatan kepada orang lain, karena peserta diskusi menunjukkan sikap yang tidak tulus mencari-cari alasan tidak berusaha untuk mencari tau. Tuturan tersebut akan menjadi santun apabila si penutur (peserta diskusi) merendahkan hati untuk berusaha mencari tahu sisa waktu pembelajaran bahasa Indonesia kepada teman sekelasnya yang memiliki jam.

\section{e. Penyimpangan Maksim Permufakatan}

Dari hasil penelitian ditemukan beberapa tuturan yang menyimpang dari maksim Penghargaan. Salah satu tuturannya, yaitu "No...Why?". Dari tuturan tersebut, terlihat si penutur menunjukkan sikap yang tidak santun kepada mitra tuturnya. Karena tuturannya, yakni "No...Why?" atau sama artinya dengan “Tidak... Kenapa?" merupakan kalimat yang menolak permintaan penyaji untuk membantu menjawab pertanyaan, sehingga tuturan tersebut menyimpang maksim permufakatan. Tuturan tersebut akan menjadi santun apabila si penutur turut membantu mitra tuturnya dalam menjawab pertanyaan tersebut. 


\section{f. Penyimpangan Maksim Kesimpatian}

Dari hasil penelitian ditemukan beberapa tuturan yang menyimpang dari maksim Penghargaan. Salah satu tuturannya, yaitu "Нииии...”. Data tersebut menyimpang dari maksim kesimpatian karena si penutur (peserta diskusi) tidak memberikan rasa simpati kepada mitra tuturnya. Tuturan pada data tersebut tidak santun karena tuturan pihak peserta diskusi, yakni "Нииии..." terlihat jelas meledek pihak penyaji yang melakukan kesalahan pada saat menjawab pertanyaan, sehingga tidak memberikan rasa simpati yang tulus bagi orang yang salah.

\section{Peringkat Penyimpangan Kesantunan Berbahasa Siswa}

Dari anaisis data yang dilakukan peneliti menemukan penyimpangan yang paling dominan muncul dalam pembelajaran bahasa Indonesia siswa kelas VII SMP Negeri 1 Labuhan Deli adalah berupa penyimpangan prinsip kesantunan dengan maksim kebijaksanaan sebanyak 24 tuturan (37,5\%) dengan jumlah keseluruhan sebanyak 64 tuturan.

\section{PEMBAHASAN HASIL PENELITIAN}

\section{Realisasi Kesantunan Berbahasa Siswa}

Dalam pembelajaran bahasa Indonesia siswa kelas VII SMP Negeri 1 Labuhan Deli ditemukan data pemenuhan prinsip kesantunan berbahasa dengan maksim kebijaksanaan sebanyak 31 tuturan dari jumlah keseluruhan sebanyak 90 tuturan dan 97 skala ketidaklangsungan (indirectness scale). Dari data tersebut dapat diketahui bahwa kesantunan berbahasa sangat dipengaruhi oleh peringkat langsung atau tidak langsungnya maksud sebuah tuturan, misalnya:

"Saya Iqbal Nasution, saya berasal dari kelompok enam. Saya ingin bertanya. Apa itu gurindam?”

Kalimat di atas merupakan salah satu contoh tuturan yang memenuhi skala ketidaklangsungan (indirectness scale). Tuturan tersebut dikatakan memenuhi 
skala ketidaklangsungan karena sebelum mengajukan pertanyaan, si penutur memperkenalkan diri dan asal kelompok kepada mitra tuturnya. Tuturan di atas terlihat santun karena si penutur mengajukan pertanyaannya tidak secara langsung. Hal tersebut juga diperkuat oleh Rahardi (2005: 67), yang mengemukakan bahwa skala ketidaklangsungan atau indirectness scale menunjuk kepada peringkat langsung atau tidak langsungnya maksud sebuah tuturan. Semakin tuturan itu bersifat langsung akan dianggap semakin tidak santunlah tuturan itu. Demikian sebaliknya, semakin tidak langsung, maksud sebuah tuturan, akan dianggap semakin santunlah tuturan itu.

\section{Penyimpangan Prinsip Kesantunan Berbahasa Siswa}

Dalam pembelajaran bahasa Indonesia siswa kelas VII SMP Negeri 1 Labuhan Deli, peneliti menemukan data tuturan yang menyimpang terhadap prinsip kesantunan berbahasa dengan jumlah keseluruhan sebanyak 64 tuturan. Penyimpangan prinsip kesantunan berbahasa tersebut berupa penyimpangan satu maksim, dua maksim, dan tiga maksim sekaligus dalam satu tuturan. Maksim yang paling banyak disimpangkan adalah maksim kebijaksanaan, yaitu berupa penggunaan diksi yang kasar (misalnya: paok, bodoh), memerintah secara langsung (misalnya: Diam kau!), dan menegur secara langsung (misalnya: Wooiii...!!! Suara...).

\section{Peringkat Penyimpangan Kesantunan Berbahasa Siswa}

Penyimpangan prinsip kesantunan yang dominan muncul dalam pembelajaran bahasa Indonesia siswa kelas VII SMP Negeri 1 Labuhan Deli adalah maksim kebijaksanaan, yaitu sebanyak 24 tuturan $(37,5 \%)$ dari jumlah keseluruhan sebanyak 64 tuturan. Tuturan yang menyimpang dari maksim kebijaksanaan tersebut berupa kata-kata kurang sopan dan berpotensi membuat mitra tutur merasa sakit hati, misalnya penggunaan kata yang kasar dan tabu, misalnya: 


\section{"Mampus..." \\ "Masih Pagi ini bodoh..." \\ "Oalahh...Diamlah kau sikit!”}

Data di atas merupakan beberapa contoh tuturan yang tidak santun karena ketika bertutur siswa tersebut menggunakan diksi yang kasar, memerintah secara langsung disertai dengan dorongan emosi (terkesan marah) terhadap mitra tuturnya.

Banyaknya tuturan tidak santun yang menyimpang dari maksim kebijaksanaan disebabkan oleh siswa (peserta tuturan) yang salah dalam memilih kata ketika bertutur, peserta diskusi terkesan menggunakan diksi yang kasar atau vulgar, memerintah dan memberi saran kepada mitra tuturnya secara langsung, menegur dengan diksi kasar, menolak dengan nada tinggi (terkesan penutur marah) serta menolak dengan diksi yang kasar.

\section{PENUTUP/KESIMPULAN}

1. Realisasi kesantunan berbahasa siswa dalam pembelajaran bahasa Indonesia siswa kelas VII SMP Negeri 1 Labuhan Deli dapat dilihat dari terpenuhinya maksim kebijaksanaan dengan jumlah 31 tuturan dan skala ketidaklangsungan dengan jumlah 97 tuturan.

2. Penyimpangan prinsip kesantunan berbahasa yang ditemukan dalam pembelajaran bahasa Indonesia siswa kelas VII SMP Negeri 1 Labuhan Deli meliputi penyimpangan satu maksim, penyimpangan dua maksim, dan penyimpangan tiga maksim sekaligus dalam tuturan. Penyimpangan tersebut dapat dilihat dari tidak terpenuhinya maksim kebijaksanaan sebanyak 31 tuturan.

3. Penyimpangan prinsip kesantunan yang dominan muncul adalah maksim kebijaksanaan, yaitu sebanyak 24 tuturan $(37,5 \%)$ dari jumlah keseluruhan sebanyak 64 tuturan. 


\section{DAFTAR PUSTAKA}

Arikunto, Suharsimi. 2002. Metodologi Penelitian. Jakarta: PT. Cipta Karya.

Ishariyanti, dkk. 2015. “Kesantunan Berbahasa dalam Kegiatan Diskusi Siswa Kelas XI SMK Dinamika Lampung Utara. Magister Pendidikan Bahasa dan Sastra Indonesia. Universitas Lampung.

Rahardi, Kunjana. 2005. Pragmatik: Kesantunan Imperatif Bahasa Indonesia. Jakarta: Erlangga.

Safitri, Kurnia.2014. Penyimpangan Prinsip Kesantunan Berbahasa dalam Interaksi Belajar Mengajar Bahasa Indonesia Siswa Kelas VIII SMP Negeri 3 Sewon. Hal 65-66, Universitas Negeri Yogyakarta, 2014.

Sirait, Melda F. 2013. Kesantunan Berbahasa Indonesia Pada Tuturan Lisan Siswa Kelas VII SMP Negeri 3 Air Putih Tahun Pembelajaran 2012/2013.Universitas Negeri Medan, 2014. 